\title{
PENGENDALIAN INTERNAL ORGANISASI KEAGAMAAN DI KOTA SALATIGA
}

\author{
Krisnawati Kamaseto Tandi Senga ${ }^{1}$, Ika Kristianti ${ }^{2}$ \\ ${ }^{12}$ Fakultas Ekonomika dan Bisnis Universitas Kristen Satya Wacana \\ e-mail: 232016101@student.uksw.edu
}

\begin{abstract}
Abstrak
Tujuan dari penelitian ini adalah untuk menggambarkan pengendalian internal dari organisasi keagamaan di Kota Salatiga dan memberikan penilaian terhadap perbedaan kebijakan maupun prosedur yang terdapat pada organisasi keagamaan di Kota Salatiga. Pengendalian internal adalah merupakan suatu proses integral yang dilakukan untuk mengatasi setiap risiko yang ada dan untuk memberikan kepastian dalam pencapaian misi entitas dengan mencapai tujuan umum. Penelitian ini merupakan penelitian kualitatif, perolehan data dengan metode wawancara dan observasi terhadap lima organisasi keagamaan di Kota Salatiga yang mewakili beberapa agama. Hasil penelitian ini menunjukkan bahwa semua organisasi sudah menerapkan dasar-dasar dari sistem pengendalian internal yang baik. Hal ini menunjukkan bahwa organisasi keagamaan mampu meningkatkan pengendalian internal mereka dengan memulai hal dasar untuk mengamankan aset yang mereka miliki sehingga hingga saat ini belum terdapat peyimpangan yang bersifat signifikan terhadap organisasi.
\end{abstract}

Kata kunci : Kebijakan pengendalian internal,organisasi keagamaaan, pengendalian internal

\begin{abstract}
The purpose of this study was to describe the internal control of religious organizations in Salatiga and provide an assessment of the differences in policies and procedures contained in the religious organizations in Salatiga. Internal control is an integral process that is done to address any risks that exist and to provide certainty in achieving the mission of the entity to achieve a common goal. This study is a qualitative research, data acquisition with interview and observation of the five religious organizations in Salatiga representing several religions. The results of this study indicate that all organizations had to apply the basics of a good internal control system. This suggests that religious organizations can improve their internal control by starting the basics to secure their assets so that to date there has been no divergence that is significant to the organization
\end{abstract}

Keywords : Internal control policy, religious organizations, internal control. 


\section{PENDAHULUAN}

Pendidikan Pengendalian internal dalam setiap organisasi berbeda, baik dalam organisasi laba maupun nirlaba khususnya organisasi keagamaan. Menurut Adhi dan Kristanto (2017)pengendalian internal merupakan suatu rencana dan metode dari organisasi yang akan digunakan untuk menjaga aset, untuk memperoleh informasi yang akurat serta dapat diandalkan, mendorong jalannya efisiensi organisasi dan juga memperbaiki organisasi, serta mendorong kepatuhan organisasi terhadap ketentuanketentuan yang sudah ditetapkan. Pengendalian internal merupakan kunci dari baik atau tidaknya pertumbuhan dan aktivitas dalam suatu organisasi baik itu organisasi laba maupun nirlaba. Pengendalian internal sendiri menurut The Committee of Sponsoring Organizations of the Treadway Commission (COSO) merupakan proses yang dirancang agar dapat memberikan keyakinan memadai tentang pencapaian tujuan pada akuntabilitas, efektivitas dan efisiensi dari kegiatan operasi, keandalan dari pelaporan keuangan, dan kepatuhan terhadap ketentuan atau ketetapan yang berlaku serta hukum yang ada (Bowrin, 2004).

Pengendalian internal dari organisasi keagamaan tentu juga memiliki berbagai macam penyelewengan hingga pada proses hukum seperti kasus penggelapan uang yang dilakukan oleh mantan Bendahara Jemaat Gereja Masehi Hari Ketujuh Universitas Advent Indonesia dimana penyelewengan yang dilakukan adalah penggelapan uang persembahan buka-tutup tahunan, uang bantuan baptisan dari kantor Konferensi Advent Jawa Barat, uang bunga bank, uang bantuan pembelian LCD, dan lainnya (Jabarekspres, 2018). Penyelewengan lainnya juga terjadi pada Gereja Kristen Setia Indonesia yang dilakukan oleh seorang pendeta yang menggelapkan dana gereja sebesar Rp575.000.000,00 yang merupakan dana ganti rugi lahan gereja yang menjadi salah satu objek yang terkena dampak dari proyek pelebaran jalan (Putra, 2019). Penggelapan dana juga dilakukan oleh Pendeta Ruddy atau Yohanes Wijaya yang meminta uang kepada jemaatnya yang diperuntukkan untuk pembangunan gereja di Semarang tetapi pendeta tidak melakukan pembangunan, melainkan membawa lari uang senilai Rp400.000.000,00 (Hatta, 2013).

Melihat tindakan penyelewengan yang dilakukan oleh anggota organisasi keagamaan maka dalam organisasi keagamaan tersebut diperlukan pengendalian internal. Organisasi keagamaan seringkali belum mengelola akuntabilitas dan pelaporan keuangan. Organisasi keagamaan bukanlah organisasi yang mengupayakan adanya laba tetapi organisasi keagamaan juga harus memiliki pengawasan yang ketat terhadap pengendaliannya. Pembentuk bagian atau bidang yang dikhususkan untuk mengevaluasi setiap kegiatan dalam organisasi perlu direncanakan dalam sebuah organisasi, karena pengendalian tersebut berhubungan langsung dengan keuangan dan jika dikendalikan dengan baik akan memberikan manfaat bagi seluruh anggota organisasi itu sendiri. Pembentukan dari bagian ini akan membuat kinerja dari organisasi akan bisa lebih teratur, terkendali, dan jauh dari penyelewengan.

Penyelewengan terhadap dana tidak hanya terjadi kepada gereja-gereja, tetapi juga terdapat penyelewengan atau penyimpangan pada masjid. Sebagai contoh, adanya penggelapan dana hibah Masjid Agung yang dilakukan oleh Ketua Yayasan Masjid Agung Sulawesi Selatan sebesar Rp5.000.000.000,00 (Padmasari, 2018). Peristiwa tersebut tentu saja sangat berpengaruh terhadap laporan keuangan organisasi seperti aset yang dimiliki oleh organisasi berupa uang jumlahnya tidak lagi sama dengan yang seharusnya karena adanya penggelapan sehingga kas menjadi berkurang. Jika tidak memiliki pengendalian berupa pengawasan, segala bentuk kecurangan bisa saja dilakukan oleh pihak yang mengatur, terutama pada bagian keuangan.

Penyelewengan tidak hanya terjadi pada organisasi laba yang memiliki banyak pos-pos atau bagian-bagian yang bisa dilakukan tindakan kecurangan tetapi juga pada organisasi keagamaan yang tentu kita pandang sebagai organisasi sakral dengan kepercayaan masing-masing organisasi. Penelitian mengenai pengendalian internal sudah pernah dilakukan, baik kepada organisasi laba dan nirlaba yang tidak fokus kepada keagamaan. Penelitian yang dilakukan oleh Habibie (2013) menemukan bahwa pengendalian internal piutang usaha pada objek sudah efektif, dimana konsep-konsep, dan prinsip-prinsip dari COSO yang digunakan sebagai acuan sudah diterapkan. Penelitian mengenai pengendalian internal juga dilakukan oleh Djanegara dan Haryadi (2007) yang menemukan bahwa internal audit memiliki pengaruh terhadap pengendalian internal penjualan. Tidak hanya kepada organisasi laba namun penelitian juga dilakukan terhadap pengendalian organisasi 
nirbala yang bukan keagamaan seperti organisasi di bidang pendidikan. Penelitian lain yang lakukan oleh Wibowo (2012) dengan hasil bahwa perancangan sistem dapat meningkatkan pengendalian internal karena mendorong adanya tuntutan untuk melaksanakan tugas sesuai dengan prosedur yang ada.

Penelitian yang berhubungan dengan keagamaan masih jarang dilakukan, sehingga penelitian ini diperuntukan untuk melihat bagaimana pengendalian internal yang diterapkan dalam organisasi keagamaan khususnya di Kota Salatiga yang tergolong mempunyai banyak agama, seperti agama Kristen, Katolik, Islam, Hindu, dan Budha. Agama Kristen sendiri masih terbagi menjadi beberapa golongan seperti Kristen Protestan, Pantekosta dan Karismatik. Tabel 1. menjelaskan tentang keanekaragaman penganut agama di Kota Salatiga (Statistik, 2010).

Tabel 1. Presentasi Penganut Agama Kota Salatiga

\begin{tabular}{lccccc}
\hline \multirow{2}{*}{ Nama Kecamatan } & \multicolumn{5}{c}{ Agama } \\
\cline { 2 - 6 } & Islam & Kristen & Katolik & Hindu & Budha \\
\hline Argomulyo & 31.138 & 6.964 & 1.439 & 18 & 166 \\
Tingkir & 31.159 & 6.359 & 1.755 & 31 & 181 \\
Sidomukti & 29.513 & 7.522 & 1.446 & 21 & 241 \\
Sidorejo & 38.084 & 9.598 & 3.429 & 36 & 204 \\
Kota Salatiga & 129.894 & 30.443 & 8.069 & 106 & 792 \\
\hline
\end{tabular}

Sumber: Data Sensus Penduduk 2010 - Badan Pusat Statistik Republik Indonesia

Berdasarkan latar belakang diatas, rumusan masalah yang ditemukan adalah bagaimanakah pengendalian internal yang dimiliki organisasi keagamaan di Kota Salatiga? Seberapa jauh pengendalian internal dalam organisasi keagamaan di Kota Salatiga mengamankan aset? Apakah terdapat perbedaan kebijakan dan prosedur pada setiap organisasi keagamaan di Kota Salatiga? Apakah pengendalian internal yang ada bisa meminimalkan resiko?

Penelitian ini bertujuan untuk mendeskripsikan pengendalian internal yang terdapat pada masing-masing organisasi keagamaan di Kota Salatiga, membandingkan kelengkapan dari kebijakan-kebijakan yang dimiliki serta prosedur yang terdapat dalam organisasi keagamaan di Kota Salatiga dan memberikan penilaian resiko beserta rekomendasinya serta saran untuk meningkatkan pengendalian internal kepada organisasi keagamaan yang terdapat di Kota Salatiga.

Setelah memperoleh hasil dari penelitian ini, diharapkan temuan yang diperoleh dapat meningkatkan pemahaman mengenai pengendalian internal dalam organisasi keagamaan di Kota Salatiga, memberikan kajian mengenai pengendalian internal yang dapat mengurangi resiko-resiko, dan diharapkan penelitian ini memiliki implikasi bagi administrator organisasi keagamaan yang tedapat di Kota Salatiga.

Agar tujuan dari suatu organisasi bisa tercapai dengan baik dan maksimal, tentu di dalam suatu organisasi harus terdapat pengendalian yang baik, sehingga dapat disimpulkan bahwa pengendalian internal adalah proses untuk memotivasi dan mendorong setiap anggota organisasi untuk melakukan kegiatan organisasi dan pencapaian tujuan organisasi. International Organization of Supreme Audit Institutions (Wardhani et al., 2019) juga menyatakan bahwa pengendalian internal merupakan suatu

proses integral yang dilakukan oleh manajemen dan anggota entitas dan dirancang untuk mengatasi setiap risiko yang ada dan untuk memberikan kepastian dalam pencapaian misi entitas dengan mencapai tujuan umum seperti melaksanakan kegiatan dengan tertib, etis, ekonomis, efisien dan efektif, menyajikan laporan keuangan yang akurat dan dapat diandalkan, mentaati setiap ketentuan dan peraturan perundang-undangan yang berlaku, mengamankan sumber daya agar terhindar dari kehilangan, penyalahgunaan dan kerusakan aset.

Konsep lainnya juga di keluarkan oleh coso yang menyatakan bahwa pengendalian internal merupakan suatu prosedur atau 
kebijakan yang dirancang agar dapat memberikan kepastian kepada manajemen bahwa tujuan dan sasaran sudah tercapai (Yuwannita dan Ariani, 2016). Pada tahun 2016, COSO membuat pembaharuan baru terhadap elemen pengendalian internal yaitu COSO Enterprise Risk Management (COSO ERM). COSO ERM memiliki beberapa elemen yang merupakan bagian dari lima elemen pengendalian internal sebelumnya yaitu: lingkungan internal, penetapan tujuan, identifikasi risiko, penilaian risiko, perlakuan risiko, aktivitas pengendalian, informasi dan komunikasi, serta pemantauan (Revi Arfamaini, S.E., 2014; Soetedjo dan Sugianto, 2018). Elemen-elemen tersebut sangat diperlukan untuk mencapai sitem pengendaliaan internal yang efektif.

Manajemen terhadap risiko dilakukan oleh perusahaan atau organisasi untuk mengelola risiko dalam lingkungan internal organisasi. Lingkungan internal tentu di pengaruhi oleh beberapa elemen seperti sistem penilaian yang diterapkan dalam perusahaan, bentuk kepemimpinan manajemen yang digunakan, proses pengambilan keputusan, dan proses penentuan wewenang serta tanggung jawab dari manajemen. Elemen tersebut memiliki pengaruh terhadap seberapa besar tingkat risiko yang akan diterima, tingkat resiko yang dapat diterima, budaya risiko serta implementasi dari ERM.

Perusahaan memiliki tujuan berbedabeda yang harus ditentukan di awal sebelum manajemen dari perusahaan memutuskan untuk mengidentifikasi setiap risiko yang ada, sehingga risiko yang terdeteksi dapat dikendalikan atau di kurangi. Tujuan dari perusahaan dapat dikelompokkan menjadi beberapa kategori yaitu sifatnya yang strategis, operasional, pemenuhan, dan pelaporan. Hal tersebut dapat membuat manajemen berpusat kepada empat aspek tujuan perusahaan dalam proses ERM. Berbagai peristiwa atau kejadian yang besar dari dalam maupun dari luar perusahaan bisa mempengaruhi proses pencapaian tujuan dari perusahaan, sehingga hal yang perlu dilakukan adalah mengidentifikasi berbagai risiko yang dapat muncul dalam perusahaan. Proses mengidentifikasi bisa dilakukan dengan menganalisa kecenderungan (tren), menganalisa kejadian masa lalu (historis), atau dengan menganalisa proyeksi masa depan.

Perusahaan akan menilai berbagai tingkatan dan besarnya risiko yang dapat mempengaruhi proses pencapaian tujuan perusahaan. Kemungkinan terjadinya dan dampak yang ditimbulkannya dapat digunakan untuk menentukan risiko-risiko yang ada, sehingga risiko tersebut dapat dikurangi sesuai dengan tingkat yang sudah ditentuan yaitu mulai dari tingkat yang memiliki risiko yang besar hingga risiko yang rendah. Tahapan yang berikutnya adalah melakukan cara yang tepat dalam menyikapi setiap risiko yang terjadi, menentukan tingkat toleransi yang dapat dilakukan terhadap risiko yang ada, dan menentukan berbagai cara yang dapat digunakan untuk menyelesaikan risiko-risiko yang telah teridentifikasi. Perlakuan terhadap risiko yang timbul adalah dengan menghidari risiko, menerima risiko, mengurangi risiko dan membagikan risiko kepada pihak lainnya.

Dalam tahapan aktivitas pengendalian kebijakan dan prosedur yang telah ditetapkan dalam perusahaan diterapkan untuk memastikan bahwa risiko-risiko yang ada telah dikendalikan sehingga proses mitigasi telah dilaksanakan dengan baik. Tahapan berikutnya adalah menyusun serta mengembangkan sistem pengembangan dari perusahaan yang terintegrasi. Informasi yang terdapat dalam perusahaan diidentifikasi apakah informasi tersebut memiliki dampak langsung terhadap perusahaan atau tidak, digolongkan berdasarkan jenisnya, dan diberikan atau dikomunikasikan dengan media serta dengan waktu yang tepat sehingga setiap anggota perusahaan dapat menjalankan tugas maupun tanggung jawab masing-masing dengan baik.

Tahapan yang terakhir adalah pemantauan setiap aktivitas pengendalian risiko yang telah ditetapkan untuk menjamin apakah mitigasi yang dilakukan terhadap risiko sudah dilakukan dengan baik. Dalam tahapan ini, data-data yang diperoleh juga dipertimbangkan baik itu data historis, data sekarang, maupun data prediksi masa depan. Data tersebut memiliki kegunaan masingmasing yaitu, data historis digunakan untuk melihat kinerja masa lalu yang berkaitan dengan pencapaian target, rencana, dan ekspektasinya, kemudian data sekarang digunakan sebagai informasi tambahan dan data masa depan digunakan untuk menyempurnakan analisa terhadap informasi. Hasil dari tahapan ini akan dievaluasi untuk dilengkapi kemudian dikembangkan untuk menghasilkan pelaksanaan sistem organisasi yang lebih baik.

Pengendalian internal sangat dibutuhkan atau sangat penting peranannya bagi organisasi nirlaba yang mengandalkan kepercayaan dari publik (Gachoka et al., 2018) untuk mencegah berbagai bentuk penipuan serta meningkatkan kinerja (Ahiabor dan Mensah, 2013). Pengendalian internal sendiri 
memiliki fungsi yaitu untuk mengamankan aset dari berbagai penyelewengan seperti pencurian oleh karyawan perampokan dan penggunaan yang tidak sah (Duncan et al., 2006; Meirini et al., 2019; Mensah, 2016), meningkatkan akurasi dan keandalan catatan akuntansi dengan mengurangi resiko kesalahan dan penyimpangan yang terjadi dalam proses akuntansi (Guryanova et al., 2019; Meirini et al., 2019; Mensah, 2016). Pengendalian internal juga memiliki empat tujuan internal yang dibagi dalam beberapa kelompok, yaitu: tujuan strategis, untuk mendukung misi entitas dengan menentukan sasaran-sasaran utama, tujuan pelaporan keuangan, untuk menjaga laporan keuangan bebas dari salah saji yang bersifat material, tepat waktu dan andal, tujuan operasional, untuk mengamankan setiap operasi entitas yang biasa disebut sebagai operasional kontrol, dan tujuan kepatuhan untuk menjaga kepatuhan terhadap hukum dan undangundang yang ada. Sasaran utama pengendalian internal adalah validitas, kelengkapan, keabsahan pencatatan umum, pengamanan, dan pertanggung jawaban (Yuwannita dan Ariani, 2016).

Dalam organisasi nirlaba yang menjadi fokus utama mengenai pengendalian adalah akuntabilitas dan pelaporan keuangan. Akuntabilitas nirlaba termasuk dalam akuntabilitas publik yang dapat diartikan sebagai kewajiban pihak berwenang untuk memberikan pertanggungjawaban, menyajikan, melaporkan dan mengungkapkan segala aktivitas dan kegiatan yang sudah menjadi tanggung jawabnya (Sari, Mintarti, dan Fitria, 2018). Elemen yang berkaitan dengan fokus tersebut adalah lingkungan internal, penetapan tujuan, identifikasi risiko, penilaian risiko, perlakuan risiko, informasi dan komunikasi dan yang terpenting adalah pemantauan. Pengendalian dalam organisasi keagamaan tentu dipengaruhi oleh beberapa faktor seperti doktrin agama, sentralisasi administrasi, dan gaya kepemipinan (Bowrin, 2004).

Pengendalian organisasi sering diartikan sebagai sistem untuk mengelola semua proses manajemen dalam pengembangan, pemilihan, dan penggunaan metode manajemen yang tepat. Pandangan mengenai pengendalian organisasi tersebut menganggap pengendalian organisasi sebagai upaya organisasi untuk meningkatkan seseorang berperilaku dalam proses pencapaian tujuan organisasi. Pengendalian organisasi sering dipandang sebagi sebuah sistem yang dikembangkan dan dikenal dengan The four levers of control. Dimensi dari sistem tersebut terdiri atas: Core
Values yang dikendalikan oleh belief systems, risks to be avoided yang dikendalikan oleh boundary systems, strategic uncertainties yang dikendalikan oleh interactive control systems, critical performance variables yang dikendalikan oleh diagnostic control systems. Keempat sistem pengendalian ini dibentuk untuk menilai aspek perilaku maupun nilai-nilai yang diterapkan oleh karyawan (Ratnamiasih et al., 2011).

Organisasi merupakan suatu hal yang mengatur dan bahkan menyusun setiap bagian yang memiliki keterkaitan satu sama lain, dimana bagian-bagian tersebut memiliki fungsi masing-masing sesuai dengan kapasitas yang dimiliki (Prabowo dan Kurniasih, 2013). Organisasi dapat diartikan sebagai wadah atau tempat bagi manusia untuk menjalin kerja sama dimana didalam tempat tersebut terdapat struktur organisasi, pembagian tugas, hak-hak serta tanggung jawab setiap anggota untuk mencapai tujuan bersama.

Organisasi keagamaan merupakan organisasi yang tergolong dalam non profit yang secara khusus bergerak dalam keagamaan seperti pada gereja, masjid, lembaga pekabaran injil, lembaga misi islam dan sebagainya (Kabuhung, 2013). Tidak hanya bergerak dalam gereja maupun masjid, organisasi kegamaan juga bergerak atau terdapat pada agama-agama yang lain, seperti Hindu, Budha dan Khong Hu Chu.

Organisasi keagamaan pada setiap agama memiliki bentuk yang berbeda-beda seperti pada gereja terdapat jenis utama bentuk organisasi yaitu Jemaat atau Congregational dan Episkopal. Bentuk dari organisasi tersebut memiliki fungsi dalam lingkungan yang berbeda-beda seperti gereja jemaat yaitu gereja Southern Baptist memiliki fungsi yang otonom dalam lingkungannya, dimana otoritas tertinggi ada pada kehendak anggota gereja individu mayoritas. Berbeda dengan gereja Episkopal yang berada di Amerika, gereja ini beroperasi di lingkungan yang diatur oleh uskup sebagai tingkat tertinggi dan otoritasnya akan didelegasikan kepada ulama (Cornell, Johnson, dan Schwartz, 2013).

Organisasi keagamaan yang terdapat di Kota Salatiga sangat beragam dengan berbagai agama seperti Kristen Pantekosta, Kristen Protestan, Kristen Karismatik, Katolik, Islam, Hindu, Budha, Khong $\mathrm{Hu}$ Chu. Kelompok-kelompok atau organisasi ini pada umumnya berinteraksi satu sama lain dengan bebas. Setiap organisasi keagamaan tentu memiliki pengendalian internal yang berbeda dan juga terdapat pengendalian yang sama. Organisasi yang memiliki kesamaan belum 
tentu memiliki keterkaitan khususnya pada bagian administrasi.

\section{METODE}

Penelitian ini merupakan jenis penelitian kualitatif deskriptif. Data yang digunakan dari penelitian ini adalah data primer yang diperoleh dari hasil wawancara serta obeservasi yang dilakukan pada organisasiorganisasi keagamaan di Kota Salatiga sebagai objek penelitian. Enam organisasi keagamaan yang terdapat di Kota Salatiga dipilih menjadi objek penelitian ini karena organisasi ini termasuk organisasi yang besar dan memiliki peran yang penting dalam kehidupan beragama di Kota Salatiga. Objek yang tersebut merupakan beberapa entitas yang juga digunakan dalam penelitian yang dilakukan oleh Ridwan (2016) yaitu Gereja Bethel Indonesia Bethell Area yang mewakili agama Kristen, Gereja Katolik Santo Paulus Miki yang mewakili agama Katolik, Parisada Hindu Dharma Indonesia (PHDI) Kota Salatiga yang mewakili agama Hindu, T.I.T.D Hok Tek Bio yang mewakili agama Budha dan Khong $\mathrm{Hu}$ Chu, dan Masjid Pandawa yang mewakili agama Islam. Organisasi ini dipilih karena adanya kesediaan dari organisasi untuk ikut mengambil bagian dalam penelitian ini. Entitas yang telah diteliti merupakan organisasi keagamaan berupa jemaat, umat, dan jamaah, Unit yang diteliti memiliki kesesuai dengan tujuan dari penelitian ini untuk melihat perspektif top-down pengendalian internal di organisaasi keagamaan. Organisasi yang telah diteliti memberikan uraian yang merupakan gambaran kasus pengendalian internal yang tidak baik karena masing-masing organisasi memiliki kebebasan untuk menerapkan pengendalian internal yang lebih maupun kurang.

Pengumpulan data dalam penelitian ini telah dilakukan dengan cara wawancara dan observasi. Wawancara telah dilakukan kepada kepala keuangan atau biasa disebut bendahara pada masing-masing organisasi keagamaan, majelis maupun pengurus organisasi keagamaan. Pengumpulan data dengan cara seperti ini telah memberikan kejelasan yang lebih dalam dan lebih luas cakupannya. Wawancara terhadap objek yang telah ditentukan dilakukan atau didasari dengan mengajukan pertanyaan-pertanyaan yang telah disiapkan sebelumnya. Pertanyaan yang telah disiapkan telah dikelompokkan berdasar kategori yaitu lingkungan pengendalian, pengendalian penerimaan, pengendalian pengeluaran, dan pegendalian lainnya terhadap aset organisasi. Hasil wawancara yang telah diperoleh, diringkasan kemudian dibandingkan. Semua perbedaan yang ditemukan telah diidentifikasi kemudian dikoreksi. Selain dari wawancara, data juga dikumpulkan dari studi yang dipublikasikan oleh organisasi-organisasi tersebut seperti data sejarah dari organisasi.

Metode analisis data yang akan digunakan pada penelitian ini menggunakan model analisis data Miles dan Huberman (2007) yang digunakan juga dalam penelitian Sari, Mintarti, dan Fitria (2018). Metode analisis ini dimulai dengan mengumpulan data di lokasi penelitian, mereduksi data, menyajikan data yang telah dikumpukan dan menarikan kesimpulan/ verifikasi. Data yang terkumpulkan diuji dengan menggunakan Triangulasi data. Pengujian dengan menggunakan Triangulasi data dilakukan dengan mengecek data berdasarkan dengan sumber dan prosedur yang digunakan dalam pengumpulan data.

\section{HASIL DAN PEMBAHASAN}

Organisasi yang dipilih untuk mewakili agama-agama yang berada di Kota Salatiga merupakan organisasi yang memiliki keberagaman. Seperti contoh organisasi Gereja Katolik Santo Paulus Miki (paroki) dan Gereja Bethel Indonesia Bethel Area merupakan organisasi Kristen yang memiliki kesamaan dalam gaya kepemimpinan yaitu kepemimpinan yang bersifat sentralisasi yaitu Gereja Katolik Santo Paulus Miki (paroki) segala sesuatunya harus diberitahu dan disetujui oleh romo dan begitupun dengan Gereja Bethel Indonesia Bethel Area yang menjadi kepala adalah gembala. Tiga organisasi lainnya cenderung memiliki gaya kepemimpinan yang bersifat desentralisasi dimana semua angggota pengurus bisa mengambil keputusan dan bersifat lebih fleksibel dimana pada Masjid Pandawa, PHDI, dan T.I.T.D Hok Tek Bio terdapat ketua yang akan memimpin jalannya dari kehidupan organisasi dibantu oleh anggota pengurus lainnya agar tujuan dari organisasi bisa tercapai. Gereja Katolik Santo Paulus Miki (paroki) merupakan gereja yang memiliki anggota terbanyak yaitu 6313 anggota jemaat dan Gereja Bethel Indonesia Bethel Area memiliki 1500 anggota jemaat. Tiga organisasi lainnya memiliki anggota yang bisa dibilang sedikit karena jenis organisasi dan jumlah dari anggotanya sendiri. Masjid Pandawa, masjid ini merupakan jenis tipologi Masjid Jami.

Organisasi-organisasi yang dipilih merupakan organisasi yang didirikan dengan latar belakang yang berbeda-beda yaitu Gereja Katolik Santo Paulus Miki (paroki) yang berada di Kota Salatiga merupakan 
Gereja yang didirikan pada 10 Februari 1928 dimana pada masa tersebut, sebagaian besar umat yang berada di Salatiga merupakan anggota Militer Belanda. T.I.T.D Hok Tek Bio merupakan tempat ibadah yang hanya menyembah satu dewa yaitu Hok Tek Cing Sien dan pada saat itu nama dari organisasi ini adalah Hok Tek Bio, Masjid Pandawa merupakan masjid yang dibangun diatas tanah milik TNI AD dan Gereja Bethel Indonesia Bethel Area berdiri karena adanya perpecahan pada gereja sebelumnya yaitu Gereja Bethel Injil Sepenuh. Terdapat dua organisasi yang berdiri dibawa sebuah naungan yaitu Gereja Katolik Santo Paulus Miki (paroki), gereja ini berdiri dibawa naungan Keuskupan Agung Semarang bersama dengan paroki-paroki yang lainnya dan Masjid Pandawa dibawa naungan Danyonif Mekanis 411 Pandawa.

Tiga organisasi lainnya berdiri sendiri dan mempertangggung jawakan kinerja yang bersifat finansial dan non finansial kepada organisasi itu sendiri. Bentuk kepengurusan dari organisasi sendiri dibagi menjadi beberapa bagian sesaui dengan organisasinya seperti pada Gereja Bethel Indonesia Bethel Area memiliki lima departemen yang berbeda dengan bidang yang berbeda-beda lagi. Setiap anggota dari organisasi tentunya memiliki tugas dan peranan yang berbeda-berbeda untuk mencapai tujuan dari organisasi dan untuk menghindari kesalahan atau penyimpangan yang bisa saja terjadi seperti penggelapan dana tetapi pada kenyataan pada organisasi PHDI, Masjid Pandawa, T.I.T.D Hok Tek Bio bendahara memiliki tugas mencatat, menyimpan dan juga melaporkan keuangan dari organisasi. Gereja Katolik Santo Paulus Miki memiliki kasir yang akan mengolah keluar masuk dari kas dan pada Gereja Bethel Indonesia Bethel Area bendahara terdiri dari tiga bagian yaitu auditor, bendahara penerimaan dan juga bendahara pengeluaran tetapi tugas dari bendahara pengeluaran akan merekap semua penerimaan maupun pengeluaran dari organisasi.

Tujuan dari organisasi-organisasi diatas juga ada yang memiliki kesamaan dan ada yang berbeda seperti semua organisasi memiliki tujuan untuk menjalankan ibadah dan memiliki fungsi sosial namun beberapa organisasi memiliki fungsi lainnya seperti Gereja Bethel Indonesia Bethel Area dan Masjid Pandawa memiliki fungsi sebagai tempat belajar dengan adanya paud pada Gereja Bethel Indonesia Bethel Area dan adanya pengajian pada Masjid Pandawa. Gereja Bethel Indonesia Bethel Area juga memiliki fungsi kesehatan karena memiliki sebuah klinik yang terbuka untuk umum. Semua organisasi melakukan rapat atau pertemuan untuk membicarakan programprogram kedepannya. Pertemuan yang diadakan pada Gereja Bethel Indonesia Bethel Area hanya membahas program besar dan program-program dari departemen akan dibahas oleh departemen sendiri dengan sepengetahuan gembala. Pertemuan pada organisasi lainnya dilakukan untuk membahas keseluruhan program kedepannya. Satusatunya organisasi yang membahas anggaran dan realisasi dari anggarannya pada pertemuan rapat adalah Gereja Katolik Santo Paulus Miki.

Setiap organisasi didorong untuk memiliki kode resmi dalam pelaporan keuangannya namun pada organisasi yang diteliti hanya Gereja Katolik Santo Paulus Miki yang memiliki kode resmi formal mengenai pelaporan keuangan kepada Keuskupan Agung Semarang, tetapi setiap paroki tidak harus mengkuti semua isi dari petunjuk tersebut. Setiap paroki seharusnya atau wajib memiliki pedoman tersendiri dalam menyusun laporan keuangannya, namun tidak boleh jauh dari pedoman yang telah diterbitkan oleh keuskupan yang membawahi. Laporan yang diterbitkan oleh Gereja Katolik Santo Paulus Miki disusun dengan menggunakan pedoman yang dimiliki sendiri oleh gereja tetapi tetap mengacu kepada Petunjuk Pelaksanaan Akuntansi Paroki 2018 dan akan diperbaharui seiring dengan berkembangnya zaman agar memiliki sistem pengendalian yan baik. Orangorang yang bertanggung jawab dalam pembuatan laporan pada Gereja Katolik Santo Paulus Miki merupakan karyawan yang benarbenar memiliki kemampuan pada bidang tersebut. Laporan dari Gereja Katolik Santo Paulus Miki pun tidak hanya diberikan kepada Keuskupan Agung Semarang tetapi juga diberikan kepada ketua wilayah sebagai perwakilan dari umat. Berbeda dengan yaitu PHDI, T.I.T.D Hok Tek Bio, Masjid Pandawa, dan pada Gereja Bethel Indonesia Bethel Area yang belum memiliki panduan resmi dalam pembuatan laporan keuangan tetapi bendahara yang mencatat sudah memiliki pengetahuan dasar mengenai pelaporan.

PDHI menerbitkan laporan setiap enam bulan sekali setiap selesainya perayaan nyepi dan akan diberikan kepada seluruh umat. T.I.T.D Hok Tek Bio hanya memberikan laporan keuangan setiap enam sekali namun hanya diberikan kepada anggota pengurus, pengawas dan pembina. Berbeda dengan Masjid Pandawa yang memberikan laporan keungan kepada jama'ah melalui mading bersamaan dengan laporan pembangunan dari 
Masjid Pandawa yang sedang berlangsung, dimana laporan ini tetap diperiksa juga oleh bendahara dan ketua walaupun terdapat panitia yang dikhususkan untuk pembangunan. Tidak hanya diberikan kepada jama'ah tetapi laporan yang telah dibuat akan diserahkan kepada staf batalion untuk diperiksa dan juga pembina dari masjid sendiri, karena Masjid Pandawa kepengurusan berada dibawah perlindungan Danyonif Mekanis 411 Pandawa. Gereja Bethel Indonesia Bethel Area tidak memberikan laporan keuangan kepada anggota jemaat namun jemaat diberikan kebebasan untuk melihat laporan keuangan dari organisasi pada kantor dari pengurus.

Pengurus-pengurus yang terpilih dalam setiap organisasi merupakan pengurus yang dibutuhkan pada bidang masing-masing dengan syarat sesuai bagian yang dibutuhkan. Tetapi pemilihan pengurus dilakukan dengan cara yang berbeda-beda pada Gereja Katolik Santo Paulus Miki pengurus dipilih dari berbagai wilayah sebagai perwakilan berbeda dengan Masjid dan T.I.T.D Hok Tek Bio yang ditentukan oleh pembina dari organisasi sesuai dengan rekomendasi umat maupun jama'ah. Pada PHDI pengurus merupakan sukarelawan yang memberi diri untuk membantu jalannya dari organisasi. Berbeda dengan Gereja Bethel Area merupakan pengurus yang diplih atas persetujuan dari gembala. Masa jabatan dari kepengurusan tiap-tiap organisasi berbedabeda tapi pada PHDI kepengurusan belum memiliki masa tertentu mengenai penggantian pengurus seperti pada T.I.T.D Hok Tek Bio, Masjid Pandawa, dan juga Gereja Katolik Santo Paulus Miki memiliki masa selama lima tahun kemudian akan digantikan berbeda dengan Gereja Bethel Area yang melakukan penggantian pengurus setiap dua tahun sekali. Kode resmi untuk perilaku dari setiap pengurus belum dibentuk pada semua organisasi yang seharusnya dibentuk agar setiap pengurus bisa menjalankan tugasnya serta bagaimana dalam beretika.

Dalam sebuah organisasi sebaiknya diadakan sebuah kegiatan untuk mengontrol setiap pengurus seperti melakukan rapat evaluasi. Rapat evaluasi hanya dilakukan organisasi dengan waktu yang berbeda-beda seperti Gereja Katolik Santo Paulus Miki melakukan rapat rutin setiap bulannya dan pada akhir tahun setiap bidang akan melaporkan pertanggung jawaban selama satu periode atau satu tahun dan juga program periode berikutnya dengan menyertakan asumsi, resiko dan bagaimana cara mengatasinya dan program selanjutnya juga harus disetujui oleh setiap pengurus agar dalam menjalankannya setiap pengurus tetap ikut berpartisipasi dan juga program harus disetujui oleh Romo serta program tersebut sesuai dengan yang diharapkan dari pusat. Gereja Bethel Area melakukan rapat besar setiap satu kali dalam satu tahun dimana dalam rapat ini semua akan membahas mengenai program besar yang akan direncanakan dan setiap departemen juga akan melakukan rapat atau pertemuan pada setiap enam bulan sedangkan T.I.T.D Hok Tek Bio melakukan pertemuan untuk membahas kegiatan sebelum melakukan kegiatankegiatan terutama untuk kegiatan rutin dari organisasi dan jika terdapat kendala pengurus akan melaporkan kepada pembina dan pengawas untuk mengatasinya. Rapat pada PHDI masih sangat jarang dilakukan seperti yang dikatakan narasumber karena kesibukan pengurus sehingga pembahasan dilakukan melalui media sosial. Pertemuan yang dilakukan oleh Masjid Pandawa sangat berbeda dengan organiasi lain karena organisasi ini melakukan pertemuan setiap hari jumat setelah sholat jumat dan pertemuan ini dilakukan untuk membahas rencana kedepannya terutama mengenai pembangunan yang sedang berlangsung.

Resiko dalam sebuah organisasi tentu saja bisa muncul kapan saja sehingga setiap organisasi didorong untuk bisa mengatasi setiap resiko yang bisa saja muncul seperti pada organisasi yang telah dipilih, setiap bidang yang memiliki resiko yang dianggap serius telah memiliki pengendalian untuk mengatasi dan bahkan mencegah seperti dengan menyiapkan cadangan dan penyimpanan aset berharga pada tempat yang aman seperti pada Gereja Katolik Santo Paulus Miki laporan setiap tiga tahun sekali akan diperiksa oleh supervisi untuk menyesuaikan apakah laporan keuangan telah sesuai dengan pedoman yang sudah ada, prosedur sudah dijalankan dengan seharusnya atau tidak, dan juga dilakukan melakukan pembenahan terhadap pedoman jika diperlukan. Berbeda dengan Gereja Bethel Area mereka memiliki auditor yang akan memeriksa setiap laporan departemen dan rekapan dari bendahara pengeluran setiap bulannya. Tiga organisasi lainnya belum melakukan hal tersebut hingga laporan dari organisasi masih memiliki cela untuk terjadinya penyimpangan.

Setiap organisasi tentu memiliki tujuan, tujuan tersebut dicapai dengan membentuk program-program seperti pada organisasi keagamaan di Kota Salatiga PHDI selalu menyelesaikan tujuannya dengan mengadakan acara rutin tetapi empat 
organisasi lainnya belum menyelesaikan programnnya sehingga program tersebut di lanjutkan untuk periode selanjutnya dan bahkan dihapuskan. Seperti pada T.I.T.D Hok Tek Bio dan Masjid Pandawa belum mencapai tujuan sebagai fungsi sosial yaitu membantu orang-orang khusus yang benar-benar membutuhkan pertolongan karena keterbatasan sumber daya. Begitupu dengan Gereja Bethel Area dan Gereja Katolik Santo Paulus Miki program yang belum tercapai pada periode tersebut akan dilanjutkan ke periode selanjutnya.

Sebagian besar penerimaan organisasi diterima dalam bentuk tunai sehingga resiko untuk penyalahgunaannya sangat tinggi. Penerimaan yang diperoleh oleh organisasi pun terbagi menjadi beberapa kategori seperti pada Gereja Katolik Santo Paulus Miki penerimaan yang diperoleh oleh gereja terbagi menjadi beberapa yaitu persembahan setiap minggu, persembahan perpuluhan, persembahan pembangunan, sumbangan umat, pengembalian sisa realisasi anggaran. Tidak berbeda jauh dengan Gereja Bethel Area yaitu persembahan ucapan syukur, persembahan perpuluhan, dan persembahan pembangunan. Organisasi yang lainnya seperti PHDI memperoleh penerimaan melalui kotak sumbangan dan juga persembahan dari anggota luar yang ingin turut membantu organisasi dan juga diperoleh atas urunan dari setiap anggota untuk mendukung kegitan yang akan diselenggarakan. Penerimaan yang diperoleh dari T.I.T.D Hok Tek Bio diterima dari donatur dan pendukung dimana dana tersebut akan dikelola langsung oleh pengurus baik untuk pengembangan dan juga untuk pemeliharaan aset yang dimiliki oleh organisasi dan akan dicatat oleh bendahara organisasi pada buku yang dimiliki. Tidak hanya melalui donatur dan pendukung namun penerimaan juga diperoleh dari kotak sumbangan dari organisasi. Berbeda dengan Masjid Pandawa, penerimaan yang terdapat pada organisasi ini dibedakan menjadi dua bagian yaitu zakat, Infak, Sodaqoh dari jama'ah yang diperoleh pada setiap sholat jum'at pada kotak amal dan juga penerimaan dari donatur tetap masjid. Pemasukan yang kedua merupakan jenis pemasukan yang diperoleh dari Badan Usaha Masjid (BUM). Penerimaan yang diperoleh setiap pembukaan kotak amal akan langsung diumumkan pada sholat jum'at minggu berikutnya dengan cara lisan dan penerimaan yang di khusukan untuk pembangunan akan langsung dikelolah oleh tim dari pembangunan sendiri. Penerimaan lainnya juga diperoleh dari biaya parkir yang digunakan untuk memberi upah kepada pekerja yang bertugas di masjid khususnya untuk penjaga parkir dan kebersihan dari masjid.

Pencatatan atas adanya penerimaan pada masing-masing organisasi juga berbeda seperti pada Gereja Katolik Santo Paulus Miki penerimaan jika diterima langsung oleh bendahara bisa dicatat langsung oleh bendahara tetapi tidak disertakan dengan slip penerimaan namun jika yang menerima kas adalah kasir dan keuangan, bagian tersebut wajib membuat slip penerimaan dan akan diserahkan pada saat menyerahkan laporan bulanan. Penerimaan yang merupakan persembahan hari minggu akan dihitung berdasarkan waktu ibadah karena di Gereja Katolik Santo Paulus Miki terdapat tiga kali ibadah. Penghitungan persembahan akan dilakukan oleh petugas yang telah dijadwalkan yang merupakan perwakilan dari lingkungan didampingi oleh pengawas pada suatu ruangan khusus yang tertutup. Setelah melakukan penghitungan semua anggota yang hadir dalam perhitungan tersebut akan melakukan tanda tangan sebagai bukti dan membuat berita acara sebagai bentuk tanggung jawab terutama jika diterimanya amplop yang tidak memiliki isi atau kosong. Berita acara mengenai hal tersebut akan diserahkan bersama dengan bukti amplop tersebut. Uang kas yang diterima pada hari tersebut akan disimpan dalam brankas dan setiap minggunya uang tersebut disetorkan ke bank namun sebelum menyetorkan akan dilakukan penghitungan ulang oleh bendahara dan pengawas dan biasanya dilakukan hari senin. Uang yang akan disetorkan akan dijemputkan langsung oleh petugas dari bank dan jika pihak dari bank belum bisa mengambilkan setoran, uang tunai tersebut akan tetap disimpan dalam brankas. Slip setoran pada minggu tersebut akan simpan sebagai bukti adanya penerimaan bersama dengan bukti-bukti yang mendukung lainnya. Berbeda dengan T.I.T.D Hok Tek Bio, PHDI, dan Masjid Pandawa setiap penerimaan akan langsung dicatat oleh bendahara dan akan disimpan langsung oleh bendahara, tetapi pada T.I.T.D Hok Tek Bio dan Masjid Pandawa jika jumlah kas sudah relatif banyak maka akan segera disetorkan kepada bank. Pencatatan penerimaan Gereja Bethel Area berbeda dari organisasi lainnya karena penerimaan akan dicatat oleh bendahara pada buku catatan yang telah ditetapkan. Pencatatan akan dilakukan terhadap penerimaan berupa kas dan kemudian akan disetorkan ke bank pada hari selasa telah dilakukan penghitungan ulang. Kas yang belum disetorkan akan disimpan dalam 
brankas. Kas yang diterima dalam bentuk transfer akan direkonsiliasi setiap hari selasa dan untuk penerimaan tersbut diterima dengan adanya nama tercatat secara langsung sehingga tidak ada konfirmasi lagi dari pihak yang mentransfer. Penerimaan yang masuk terhadap departemen-departemen akan langsung dikelola setiap departemen dan untuk pertanggung jawaban akan langsung diberikan kepada auditor untuk diaudit. Penerimaan yang masuk kepada bendahara tiga yang ditujukan kepada departemen akan langsung diberikan kepada departemen tersebut dan bendahara tiga tidak akan mencatat penerimaan tersebut. Rekonsiliasi oleh bendahara organisasi hanya dilakukan oleh Gereja Katolik Santo Paulus Miki dan Gereja Bethel Area setiap bulannya.

Penerimaan maupun pengeluaran setiap organisasi tentu memiliki proses yang berbeda-beda seperti pada pengeluaran yang terdapat pada Gereja Katolik Santo Paulus Miki dan Gereja Bethel Area penerimaan kedua organisasi ini diotorisasi oleh dua orang yaitu bendahara dan romo/gembala. Pengeluaran kedua organisasi ini yang jumlahnya relatif besar harus diajukan kepada romo/gembala dalam bentuk proposal pengajuan untuk disetujui kemudian pencairan akan segera dilakukan oleh kasir. Jika kas pada kasir Gereja Katolik Santo Paulus Miki tidak mencukupi, bendahara akan melakukan penarikan di bank untuk diberikan kepada kasir. Pengeluaran pada Gereja Katolik Santo Paulus Miki yang memiliki jumlah relatif besar terutama untuk inventaris akan dilakukan dengan surat perpomohan yang berbeda dan bukti yang berbeda juga. Pengeluaran pada Gereja Bethel Area dicatat langsung oleh bendahara dua yang sekaligus akan merekap penerimaan dan pengeluran untuk diberikan kepada bendahara satu selaku auditor dari Gereja Bethel Area. Pengeluaran dari Gereja Bethel Area yang telah disetujui akan dicairkan oleh bendahara dua dengan dokumen yang telah ditandatangani oleh gembala dan juga bendahara. Setiap pengeluaran pada kedua organisasi akan dicatat dan diberikan nomor beserta dengan bukti pengeluarannya. Bukti pengeluaran akan langsung dilampirkan pada catatan keuangan yang dimiliki bendahara.

Pencairan atau pengeluaran kas pada tiga organisasi lainnya yaitu PHDI, Masjid Pandawa dan T.I.T.D Hok Tek Bio dicatat bersama dengan bukti yang berkaitan. Setiap pengeluaran harus diketahui oleh pengurus inti dan jika terdapat pengeluaran mendadak bendahara akan langsung mengeluarkan kas sesuai dengan kondisi yang ada. Pengeluaran tetap harus diberitahukan kepada pengurus inti beserta dengan penjelasannya, kemudian disampaikan kepada pengurus lainnya. Pengeluaran dari Masjid Pandawa tidak hanya digunakan untuk masjid sendiri tetapi juga digunakan untuk membantu pembangunan masjid lain dan sosial masyarakat dan pengeluaran ini juga langsung disatukan oleh bendahara pada buku catatan.

Pengeluaran dalam semua organisasi tidak menggunakan cek namun jika terdapat pengeluaran yang mengharuskan terjadinya transfer maka akan dilakukan penarikan tunai dari bank terlebih dahulu yang memiliki rekening kemudian disetorkan langsung kepada nomor rekening yang akan dituju. Bukti dari penyetoran tersebut akan langsung disimpan oleh bendahara sebagai lampiran pengeluaran. Pada Gereja Bethel Area dan Gereja Katolik Santo Paulus Miki pencairan yang telah dilakukan dan batal untuk digunakan akan disetorkan kembali, namun bukti pengeluaran dan menyetoran kembali akan disimpan oleh bendahara untuk dilaporkan.

Aset lainnya pada setiap organisasi tentu harus diamankan dengan sebaikbaiknya, seperti yang dilakukan Gereja Katolik Santo Paulus Miki, T.I.T.D Hok Tek Bio, Gereja Bethel Area, dan Masjid Pandawa dengan menetapkan adanya penjaga yang akan menjaga gedung dan bahkan peralatan dari organiasasi dan juga dengan memasangkan CCTV untuk dihindarkan dari pencurian, walaupun beberapa aset berada pada lemari terkunci dan juga ruangan terkunci terutama untuk surat berharga dari organisasi disimpan dalam brankas yang kuncinya dipegang oleh orang yang telah ditentukan oleh pengurus. Berbeda dengan PHDI, organisasi ini belum memiliki penjaga khusus dari pura dan pura dibuka (tidak dikunci).

Aset berupa tanah dan bangunan dan aset lainnya juga terdaftar dengan nama organisasi pada Gereja Katolik Santo Paulus Miki, T.I.T.D Hok Tek Bio, Gereja Bethel Area, dan PHDI. Berbeda dari keempat organisasi tanah dari Masjid Pandawa masih diatas namakan tanah milik TNI AD. Begitupun dengan rekening yang dimiliki organiasi, beberapa rekening sudah diatas namakan organisasi yaitu Gereja Katolik Santo Paulus Miki, Masjid Pandawa, dan Gereja Bethel Area. Dua organisasi lainnya belum menggunakan rekening khusus tapi masih menggunakan perwakilan. Rekening Gereja Katolik Santo Paulus Miki ditanda tangani oleh romo dan bendahara, Masjid Pandawa ditanda tangani oleh ketua dan bendahara, dan Gereja Bethel ditanda tangani oleh gembala dan bendahara. 
Skor evaluasi pengendalian internal dan ringkasan statistik dari lima organisasi keagamaan di Kota Salatiga disajikan dalam
Tabel 2 dan dibagi dalam empat bidang eksposur yang memiliki risiko.

Tabel 2. Skor Evaluasi Pengendalian Internal Seluruh Organisasi Keagamaan di Kota Salatiga

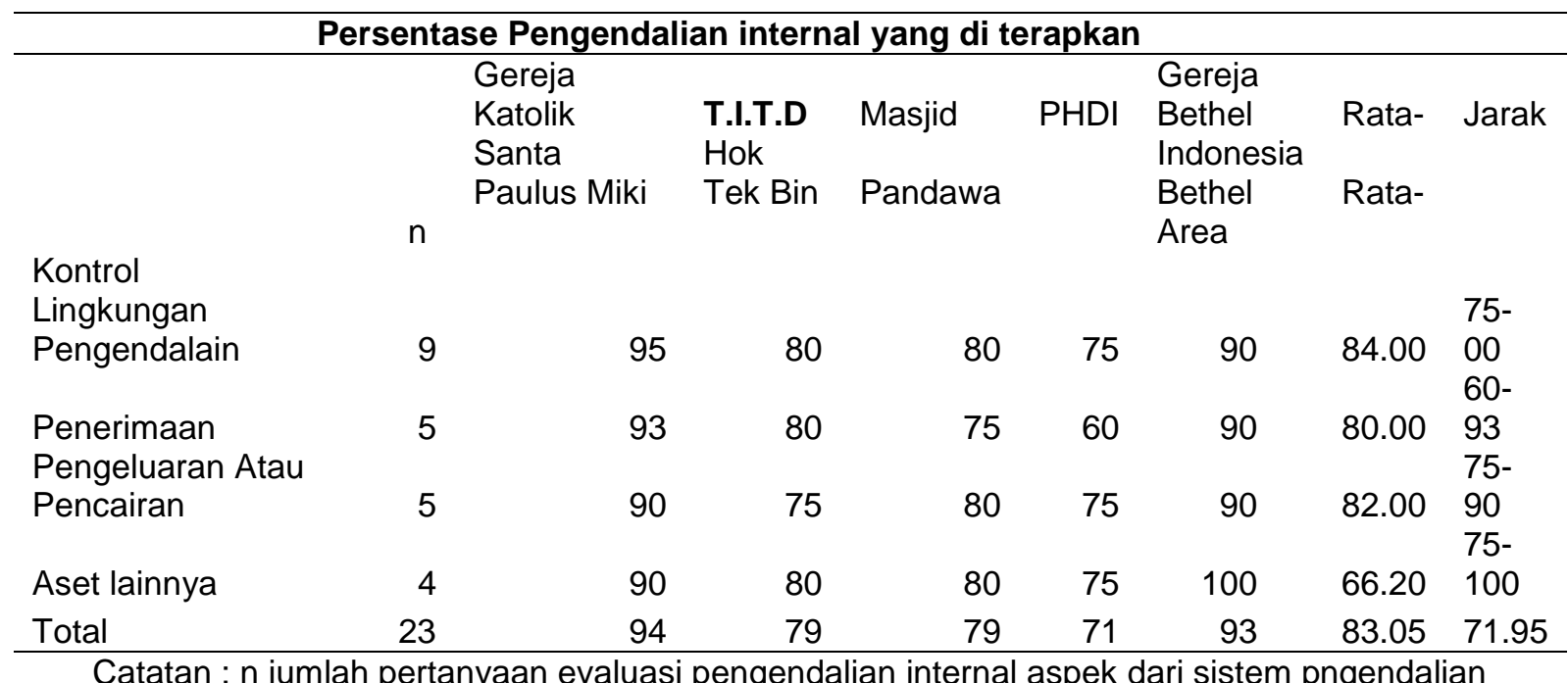

Seperti yang terdapat dalam Tabel 2 sistem pengendalian internal organisasi keagamaan di Kota Salatiga rata-rata yang ditunjukkan dari keseluruhan pengendalian adalah 83,05 persen. Sehingga dapat dikatakan bahwa pengendalian internal oragnisasi keagamaan di Kota Salatiga sudah baik karena skor rata-rata dari pengendalian internal telah mendekati skor 100 persen walaupun beberapa organisasi memiliki skor yang masih berada dibawa skor rata-rata. Skor dari pengendalian internal yang tertinggi terdapat pada Gereja Katolik Santo Paulus Miki yaitu 94 persen dan skor terendah terdapat pada PHDI Kota Salatiga. Dua organisasi yang lain (T.I.T.D Hok Tek Bio dan Masjid Pandawa 79 persen) memiliki skor yang lebih rendah dari skor rata-rata pengendalian internal yaitu 83,05 persen. Berdasarkan fakta dapat dilihat dari 60 tahap pengendalian dasar yang digunakan untuk menghasilkan sistem yang komprehensif, temuan ini merupakan penyebab yang dapat menimbulkan kekhawatiran. Temuan tersebut menunjukkan bahwa terdapat dua organisasi yang memiliki sistem pengendalian internal yang komprehensif yaitu Gereja Katolik Santo Paulus Miki dan Gereja Bethel Indonesia Bethel Area. Hasil ini sangat mirip dengan temuan dari Anthony R. Bowrin (2004) yaitu organisasi keagaaan yang berada di Trinidad dan Tobago rata-rata telah menerapkan 77 persen dari enam puluh pengendalian dasar yang biasanya dianjurkan untuk organisasi keagamaan
Berdasarkan Tabel 2, lingkungan pengendalian merupakan pengendalian yang memiliki kekuatan yang besar dalam sistem pengendalian internal organisasi keagamaan di Kota Salatiga. Skor rata-rata dari lingkungan pengendalian adalah 84 persen. Skor dari lingkungan pengendalian organisasi keagamaan Kota Salatiga adalah berkisar 95 persen untuk Gereja Katolik Santo Paulus Miki hingga 75 persen untuk PHDI.

Kelemahan yang sering terjadi dalam lingkungan pengendalian organisasi keagamaan di Kota Salatiga adalah pemisahan tugas sekretaris keuangan/bendahara untuk secara bersamaan melakukan tugas-tugas akuntansi seperti pencatatan, penyimpanan dan otorisasi, serta praktik yang tidak sesuai dengan prinsipprinsip pengendalian internal yang berlaku umum. Pengendalian lainnya yang masih sering dilanggar adalah laporan keuangan tidak diaudit/diperiksa oleh bagian khusus dari organisasi serta masih banyak tujuan dari organisasi belum tercapai pada beberapa organisasi keagamaan. Pertemuan yang dikhususkan untuk mengontrol pengurus belum dilakukan sepenuhnya oleh organisasi karena beberapa pengurus tidak melakukan evaluasi melainkan pertemuan dikhususkan untuk membahas program organisasi (Tabel 3).

Hasil dari Tabel 2 menunjukkan bahwa pengendalian terhadap penerimaan merupakan aspek yang tergolong lemah dari pengendalian internal organisasi keagamaan 
di Kota Salatiga yang diperiksa. Rata-rata skor evaluasi dari pengendalian penerimaan adalah 80 persen. Gereja Katolik Santo Paulus Miki memiliki sistem pengendalian penerimaan yang paling komprehensif dengan skor 93 persen dan PHDI memiliki sistem yang terendah yaitu 60 persen.

Hampir semua organisasi keagamaan tidak memberikan fotokopi catatan kepada anggota mengenai kontribusi terhadap organisasi (lihat Tabel 3). Sebagian besar karyawan dari organisasi keagamaan di Kota Salatiga memiliki akses terhadap kas yang kemudian akan disetorkan kepada bendahara untuk dicatat. Penyimpangan yang dilakukan anggota dari organisasi keagamaan untuk saat ini belum ada yang dilaporkan namun setiap organisasi menghibau agar setiap penyimpangan segera dilaporkan kepada bagian pengawas maupun audit namun untuk saat ini yang belum menyampaikan instruksi tersebut tehadap anggotanya terdapat dua organisasi keagamaan dan juga semua organiasi keagamaan tidak menyarankan adanya cek untuk persembahan dari anggota karena cek memiliki sifat yang sensitif dan memiliki resiko yang besar sehingga organisasi menghindari penerimaan dalam bentuk cek (lihat Tabel 3).

Tabel 3. Pengendalian Internal yang Paling Sering Dilanggar Organisasi Keagamaan di Kota Salatiga

\begin{tabular}{lc}
\hline \multicolumn{1}{c}{ Sifat Pengendalian } & $\begin{array}{c}\text { Jumlah organisasi keagamaan yang } \\
\text { melanggar ukuran }\end{array}$ \\
\hline $\begin{array}{l}\text { Lingkungan Pengendalian } \\
\text { Bendahara melakukan rangkap jabatan }\end{array}$ & 3 \\
$\begin{array}{l}\text { Panduan prosedur akuntansi tidak ditulis up to date } \\
\text { Tidak terdapat pengawas yang akan mengevaluasi } \\
\text { laporan keuangan }\end{array}$ & 2 \\
$\begin{array}{l}\text { Tidak adanya kode resmi pengurus dalam beretika } \\
\text { Tidak mencapai tujuan yang dikhususkan untuk satu } \\
\text { periode tertentu }\end{array}$ & 5 \\
$\begin{array}{l}\text { Tidak terdapat pertemuan khusus untuk mengevaluasi } \\
\text { program dan pembuatan anggaran tahun selanjutnya }\end{array}$ & 4 \\
$\begin{array}{l}\text { Penerimaan } \\
\text { Tidak terdapat tanda penerimaan yang diberikan kepada } \\
\text { anggota yang memberikan kontribusi }\end{array}$ & 4 \\
Tidak menyarankan adanya cek dalam pemberiaan \\
persembahan dari anggota \\
$\begin{array}{l}\text { Tidak ada instruksi kepada anggota untuk melaporakan } \\
\text { adanya kesalahan dalam pelaporan kontribusi mereka } \\
\text { kepada organisasi } \\
\text { Hanya bendahara yang mengotorisasi penerimaan } \\
\text { Tidak semua pengurus memiliki akses kepada kas }\end{array}$ \\
$\begin{array}{l}\text { Pengeluaran/pencairan } \\
\text { Tidak memberikan pre-nomor kepada pembelian yang } \\
\text { tidak diotorisasi }\end{array}$ \\
$\begin{array}{l}\text { Tidak terdapat dokumen pendukung dalam proses } \\
\text { pembelian atau pengeluaran }\end{array}$ \\
$\begin{array}{l}\text { Rekonsiliasi tidak dilakukan atau pelaksanaannya } \\
\text { ditentukan oleh bendahara }\end{array}$ \\
$\begin{array}{l}\text { Aset lainnya } \\
\text { Aset lainnya tidak dijaga oleh penjaga khusus }\end{array}$ \\
\hline
\end{tabular}

Pengendalian terhadap pengeluaran merupakan salah satu aspek kuat dari sistem pengendalian internal organisasi keagamaan di Kota Salatiga. Skor rata-rata evalusi terhadap pengendalian pengeluaran adalah 82 persen. Gereja Katolik Santo Paulus Miki dan Gereja Bethel Indonesia Bethel Area memiliki pengendalian pengeluaran yang sangat komprehensif dengan skor 90 persen dan sebaliknya skor terendah merupakan posisi dari T.I.T.D Hok Tek Bio dan juga PHDI dengan skor masing-masing 75 persen.

Seperti yang terdapat dala Tabel 3, semua organisasi keagamaan tidak menggunakan pre-nomor pesanan terhadap pembelian dan tiga dari organisasi keagamaan tidak memiliki otorisasi pengeluaran. Dua dari lima organiasi tidak memberikan atau tidak 
memiliki dokumen sebelum melakukan pengeluaran sehingga pengeluaran bisa dilakukan kapan saja tanpa dokumen pendukung dan tiga dari lima organisasi tidak menyiapkan kas kecil untuk keperluan dadakan. Terdapat dua organisasi yang harus menyetorkan ulang kas yang batal digunakan untuk pengeluaran tertentu sehingga ini menjadi sebuah kelemahan karena organisasi tidak mempertimbangkan pengajuan dengan baik sebelum menyetujui adanya pengeluaran walaupun demikian organisasi telah menyimpan slip sebagai lampiran untuk dilaporkan.

Berdasarkan Tabel 2 pengendalian terhadap aset lainnya memiliki skor rata-rata 86,2 persen. Gereja Bethel Indonesia Bethel Area memiliki skor evaluasi tertinggi yaitu 100 persen yang sudah mengasuransikan gedungnya dan skor terendah dimiliki oleh PHDI dimana aset berupa pura terbuka umum dan belum terdapat penjaga tetap dari pura. Berbeda dengan organisasi lainnya yang dijaga oleh petugas yang sudah ditentukan.

\section{PENUTUP}

Sesuai dengan Tabel 2, seluruh pengendalian internal dari lima organisasi keagamaan di Kota Salatiga dapat dibedakan menjadi dua bagian yaitu organisasi yang dinilai berdasarkan tingkat sentralisasi administrasi dan jumlah direksi yang diberikan kepada pemimpin (gaya kepemimpinan) dengan berbagai temuan yang peroleh. Dua dari lima organisasi keagamaan memiliki tingkat pengendalian internal yang berada diatas rata-rata keseluruhan organisasi sehingga dapat dikatakan organisasi cenderung memberikan sedikit kebebasan untuk menetapkan kebijaksanaan dalam administrasi. Tiga organisasi lainnya memiliki total keseluruhan skor pengendalian internal yang lebih rendah atau dibawa rata-rata sehingga organisasi ini cenderung desentralisasi dalam administrasi dan memungkinkan para pemimpin mereka memiliki cukup banyak kebijaksanaan dalam urusan administrasi.

Berdasarkan penelitian, ditemukan bahwa organisasi keagamaan yang memiliki peringkat pengendalian internal sama dengan atau lebih besar dari rata-rata skor keseluruhan organisasi merupakan organisasi yang besar dilihat dari jumlah pengikutnya (anggotanya). Sebagai contoh adalah Gereja Katolik Santo Paulus Miki yang memiliki anggota terbanyak yang diteliti. Gereja ini memiliki sistem pengendalian internal yang paling komprehensif berbeda dengan PHDI yang memiliki jumlah umat yang tergolong masih sedikit. Kedua organisasi ini sangat berbeda karena kurangnya sumber daya dalam organisasi sehingga untuk tingkatan sentralisasi administrasi kedua organisasi memiliki perbedaan yang cukup jauh, sebagai contoh adalah Gereja Katolik Santo Paulus Miki memiliki sistem pengeluaran dan penerimaan yang diotorisasi oleh beberapa orang sedangkan untuk PHDI sistem untuk pengeluaran dan penerimaan masih tergolong sangat sederhana tanpa harus terdapat sistem yang sudah ditentukan.

Berdasarkan penelitian, organisasi PHDI yang merupakan organisasi yang tergolong kecil di Kota Salatiga memiliki doktrin bahwa orang-orang yang lakukan penyalahgunaan dalam organisasi akan mendapat hukuman dari Yang Kuasa berbeda dengan organisasi lainnya yang akan menindaki setiap penyimpangan yang terjadi di dalam organisasi. Berdasarkan doktrin tersebut tingkat sentralisasi dan juga jumlah kebijaksanaan yang diberikan kepada pemimpin telah memberikan pengukuran peringkat komprehensif pengendalian internal dari gereja-gereja yang masih dibawa ratarata.

Organisasi lainnya yang masih memiliki skor dibawa rata-rata sebaiknya mendorong adanya pengendalian yang lebih atau bisa melihat pengendalian dari organisasi lainnya yang telah memiliki sistem pengendalian yang koprehensif walaupun saat ini belum terjadi penyimpangan yang belum berdampak besar bagi kehidupan organisasi.

Penelitian ini memiliki beberapa keterbatasan. Pertama, penelitian ini hanya meneliti sistem pengendalian internal pada organisasi keagamaan yang dipilih untuk mewakili beberapa agama yang ada di Kota Salatiga. Kedua, beberapa organisasi keagamaan Kota Salatiga belum memiliki panduan pengendalian yang lengkap sehingga diperlukan pemeriksaan sistem pengendalian secara langsung. Pendekatan ini tidak konsisten dengan yang digunakan untuk organisasi keagamaan lainnya. Namun, hal tersebut satu-satunya cara untuk mengetahui bahwa organisasi dapat dimasukkan dalam penelitian ini adalah organisasi ini merupakan organisasi yang mewakili agama yang diakui di Indonesia.

Ketiga, penjelasan di atas dan penilaian dari pengendalian internal di organiasi keagamaan ini mungkin tidak berlaku untuk seluruh organisasi keagamaan lainnya yang sealiran di Kota Salatiga. Keempat, dalam menghitung skor evaluasi pengendalian, semua 23 pertanyaan pengendalian internal yang sama diajukan dengan berbagai 
pertimbangan yang sesuai meskipun terdapat probabilitas yang tinggi bahwa beberapa pengendalian lebih penting daripada yang lain. Namun, hal ini diperlukan karena saat ini belum ada kriteria yang berlaku umum untuk menentukan bobot diferensial dengan berbagai kebijakan pengendalian internal dan prosedur yang direkomendasikan khusus untuk organisasi keagamaan. Akhirnya, penelitian ini mengidentifikasi adanya beberapa defisiensi pengendalian internal seluruh organisasi keagamaan. Hal tersebut merupakan keterbatasan yang berpotensi tinggi karena sifat dari defisiensi ini kemungkinan akan mempengaruhi isi dan pendekatan untuk setiap tindakan perbaikan dalam organisasi. Terlepas dari keterbatasan ini, penelitian ini membuat beberapa kontribusi untuk literatur tentang tata kelola organisasi keagamaan .

Keterbatasan sebelumnya juga menandakan adanya peluang untuk penelitian kedepannya. Sebagai contoh, mungkin berguna untuk memeriksa sistem pengendalian individu bagian-bagian ataupun departemen dari lima organisasi yang telah diteliti. Studi ini akan menjelaskan pengendalian internal seperti kebijakan, prosedur dan praktek organisasi keagamaan dan mengidentifikasi sejauh mana sistem pengendalian internal diterapkan dengan konsisten sesuai dengan yang ditetapkan oleh badan pusat organisasi keagamaan. Penelitian juga diperlukan untuk melihat alasan adanya perbedaan sistem pengendalian internal yang bisa saja ditemukan di antara organisasi keagamaan di Kota Salatiga.

\section{DAFTAR PUSTAKA}

Adhi, E., \& Kristanto, H. (2017). Korupsi dalam Pelayanan Gereja: Analisis Potensi Penyimpangan dan Pengendalian Internal. INTEGRITAS, 3, 105-136.

Ahiabor, G., \& Mensah, C. C. Y. (2013). Effectiveness of Internal Control on the Finances of Churches in Greater Accra, Ghana. Research Journal of Finance and Accounting, 4(13), 7.

Bowrin, A. R. (2004). Internal control in Trinidad and Tobago religious organizations. Accounting, Auditing \& Accountability Journal, 17(1), 121-152. https://doi.org/10.1108/09513570410525 238
Cornell, R. M., Johnson, C. B., \& Schwartz, W. C. (2013). Influence of Leadership Positions on Internal Controls and Reported Fraud In Religious Organizations. Journal of Forensic \& Investigative Accounting, 5(1), 85-125.

Djanegara, M. S., \& Haryadi, M. C. (2007). Studi Tentang Efektivitas Pengendalian Intern Penjualan. Jurnal IImiah Ranggagading, 7(1), 1-7.

Duncan, J. B., Flesher, D. L., \& Stocks, M. H. (2006). Internal Control systems in US churches An examination of the effects of church. Accounting, Auditing \& Accountability Journal, 12(2), 142-163.

Gachoka, N., Aduda, J., Kaijage, E., \& Okiro, K. (2018). The Intervening Effect of Internal Controls on the Relationship Between Budgeting Process and Performance of Churches in Kenya. Journal of Finance and Investment Analysis, 7(2), 81-107.

Guryanova, A. V, Shestakov, A. A., \& Noskov, E. G. (2019). Integration Of The Internal Control System For Financial Stability Of The Organization. The European Proceedings of Social \& Behavioural Sciences, 113-125.

Habibie, N. (2013). Analisis Pengendalian Intern Piutang Usaha Pada Pt Adira Finance Cabang Manado. Jurnal EMBA, 2(SGEM2016 Conference Proceedings, ISBN 978-619-7105-16-2 / ISSN 13142704), 1-39.

Hatta, R. T. H. T. (2013). Gelapkan Uang Jemaat Rp 400 Juta, Pendeta Ditangkap di Pedurenan. Liputan6. Retrieved from https://www.liputan6.com/news/read/613 278/gelapkan-uang-jemaat-rp-400-jutapendeta-ditangkap-di-pedurenan

Jabarekspres. (2018). Penggelapan Uang Gereja Minta Segera Diproses. Jabarekspres. Retrieved from http://jabarekspres.com/2018/penggelapa n-uang-gereja-minta-segera-diproses/ 
Kabuhung, M. (2013). Sistem Informasi Akuntansi Penerimaan Dan Pengeluaran Kas Untuk Perencanaan Dan Pengendalian Keuangan Pada Organisasi Nirlaba Keagamaan. Emba, 1(3), 339-348 https://doi.org/10.1017/CBO9781107415 324.004

Meirini, D., Andari, A. T., \& Aalin, E. R. (2019). Fixed Sample Size as an Internal Control. Integrated Journal of Business and Economics, $3(1), \quad 52$. https://doi.org/10.33019/ijbe.v3i1.110

Mensah, B. K. A. (2016). Accountability and internal control in religious organisations: a study of Methodist church Ghana. African J. of Accounting, Auditing and Finance, $\quad 5(2), \quad 95$. https://doi.org/10.1504/ajaaf.2016.07830 2

Miles, M. B., \& Huberman, A. M. (2007). Analisis Data Kualitatif, Buku Sumber Tentang Metode-metode Baru. Jakarta: Universitas Indonesia Press.

Padmasari, S. I. (2018, November 5). Terlibat kasus korupsi dana hibah, Ketua Yayasan Masjid Agung Palopo ditahan. Merdeka. Retrieved from https://m.merdeka.com/peristiwa/terlibatkasus-korupsi-dana-hibah-ketuayayasan-masjid-agung-palopoditahan.html

Prabowo, W. J. A., \& Kurniasih, L. (2013). Penerapan Akuntansi, Akuntabilitas Dan Pengendalian Internal Pada Gereja Kristen Jawa Wedi. EQUITY, 20(2), 1730.

Putra, A. (2019). Diduga Gelapkan Dana Ganti Rugi Lahan Gereja, Pendeta di Perbatasan Dipenjara. Okenews. Retrieved from https://news.okezone.com/read/2019/01/ 12/340/2003419/diduga-gelapkan-danaganti-rugi-lahan-gereja-pendeta-diperbatasan-dipenjara

Ratnamiasih, I., Govindaraju, R., Sudirman, I., \& Prihartono, B. (2011). Kepemimpinan , Pengendalian Organisasi , dan Keamanan Kerja serta Dampaknya Pada Kualitas Pelayanan Rumah Sakit di Bandung. ResearchGate, 1-10.
Revi Arfamaini, S.E., M. . (2014). Penerapan Sistem Pengendalian Intern terhadap Risiko dengan Menggunakan COSO Enterprise Risk Management (ERM) Integrated Framework pada Suatu Entitas. Prosiding Seminar Nasional Teknologi Terapan SV UGM, 52-55.

Ridwan, B. (2016). Potret Organisasi Keagamaan Dan Respon Terhadap Dinamika Kehidupan Keberagamaan Di Salatiga. Inferensi, 5(1), 101. https://doi.org/10.18326/infsl3.v5i1.101120

Sari, M., Mintarti, S., \& Fitria, Y. (2018). Akuntabilitas pengelolaan keuangan organisasi keagamaan. Kinerja, 15(2), 45.https://doi.org/10.29264/jkin.v15i2.402 9

Soetedjo, S., \& Sugianto, A. (2018). Penerapan Coso Erm Integrated Framework Dalam Mendukung Audit Forensik Untuk Menanggulangi Tindakan Kecurangan. Journal of Applied Managerial Accounting, 2(2), 262-274. https://doi.org/10.30871/jama.v2i2.944

Statistik, B. P. (2010). Penduduk Menurut Wilayah dan Agama yang Dianut. Retrieved June 8, 2019, from Badan Pusat Statistik website: https://sp2010.bps.go.id/index.php/site/ta bel?tid $=321 \& \mathrm{wid}=3373000000$

Wardhani, R. S., Fuadah, L. L., Siddik, S., Awaluddin, M., Ekonomi, F., Belitung, U. B., ... Selatan, S. (2019). Good University Governance: Budgeting Participation And Internal Control. AsiaPacific Management Accounting Journal, 14(1), 1-17.

Wibowo, I. O. (2012). Perancangan Sistem Informasi Penggajian Terkomputerisasi Dalam Rangka Meningkatkan Efektivitas, Efisiensi, Dan Pengendalian Internal Pada Yayasan Lazaris. IImiah Mahasiswa Akuntansi, 1(1), 1-17.

Yuwannita, A., \& Ariani, N. E. (2016). Analisis Hubungan Pengendalian Internal Versi Cosoterhadap Indikasi Kecurangan Laporan Keuangan Pada Baitul Qiradh Anggota Pusat Koperasi Syariah Nanggroe Aceh Darussalam. Jurnal IImiah Mahasiswa Ekonomi Akuntansi, 1(1), 199-209. 